Brit. J. vener. Dis. (1964), 40, 106.

\title{
ASYMPTOMATIC PURULENT MENINGITIS IN A TABETIC*
}

\author{
BY
}

\author{
A. J. BELSHAM $\dagger$ AND E. M. C. DUNLOP $\downarrow$
}

From Oldchurch Hospital, Romford, Essex

This report describes the discovery of asymptomatic purulent meningitis in a patient suffering from tabes dorsalis.

\section{Case Report}

A man aged 58 years was admitted to Oldchurch Hospital on September 13, 1961, for investigation of abdominal pain and vomiting of 3 weeks' duration.

History.-In 1949 he had had similar symptoms which were investigated at The London Hospital and diagnosed as due to a gastric crisis. At that time examination showed signs of tabes dorsalis and tests gave the following results:

Blood Wassermann reaction (W.R.) positive; Price's precipitation reaction (P.P.R.) positive $(1: 64)$.

Cerebrospinal fluid (C.S.F.): W.R. positive (1:32); P.P.R. positive $(1: 2)$; cells 121 /cu. mm. (mainly lymphocytes); protein $100 \mathrm{mg} . / 100 \mathrm{ml}$.; Pandy test excess globulin; Lange curve 5555544320.

Treatment had consisted of ten intramuscular injections each of $0.4 \mathrm{~g}$. bismuth at weekly intervals and 250,000 units aqueous penicillin by intramuscular injection twice daily for 12 days. In July, 1950, tests of the C.S.F. gave the following results:-W.R. positive; P.P.R. positive (1:4); cells less than $1 / \mathrm{cu} . \mathrm{mm}$.; protein $40 \mathrm{mg}$. $/ 100 \mathrm{ml}$.; Lange curve 322332.

Because of an increase in the signs of tabes and a sustained rise in titre of the serological tests for syphilis, he was given twenty daily injections each of 600,000 units procaine penicillin in August, 1950, and after this he remained symptom-free for 11 years. By 1955, the serological tests were only weakly positive (P.P.R. positive with neat serum) and they remained at this level. The C.S.F. had become normal by 1952 apart from a positive W.R. ( $1: 8)$. It had last been tested in 1955, when the W.R. was still positive and the protein content 100 $\mathrm{mg} . / 100 \mathrm{ml}$. in a specimen contaminated with blood.

Recent History. - 3 weeks before admission he had started to have attacks of central abdominal pain, burning

* Received for publication September 29, 1963.

+ Now at the North Middlesex Hospital.

$\ddagger$ Now at the Whitechapel Clinic, The London Hospital. in character, lasting a few hours, and associated with the occasional vomiting of a yellowish fluid. There was no nausea. The attacks gradually became more frequent and severe, and he had been able to retain only fluids by mouth for 3 days before entering hospital.

Examination.-He was a cheerful, garrulous, thin man, not in obvious pain and not dehydrated. The body temperature was $99 \cdot 6^{\circ} \mathrm{F}$. and the pulse rate 88 . The heart and lungs were apparently normal; the blood pressure was $110 / 65 \mathrm{~mm}$. $\mathrm{Hg}$. The abdomen was soft and moved well on respiration. There was slight epigastric tenderness but no guarding. The bowel sounds were normal and rectal examination disclosed no abnormality.

There were marked signs of tabes dorsalis: Argyll Robertson pupils; knee-jerks and ankle-jerks absent; tone, vibration sense, and deep pain sensation diminished in both legs; position sense impaired in the right foot; areas of diminished sensation to pinprick on the ulnar aspects of the forearms; facial sensation normal.

Study of the previous records suggested that the loss of tone and diminished sensation to pinprick had developed since 1955.

Radiological Examination.-Plain films of the abdomen showed gallstones, Paget's disease of the left half of the pelvis, and Charcot's disease affecting the lumbar vertebrae. A barium meal showed no other abnormality.

Lumbar Puncture (September 14): Blood-stained fluid59,500 R.B.C./cu. mm. and 20 W.B.C./cu. mm. $(80$ per cent. polymorphonuclear leucocytes, 20 per cent lymphocytes); Pandy test slight excess of globulin; protein 80 mg./100 ml.; Lange curve 1123321000; W.R. negative. These findings and those of subsequent C.S.F. examinations are summarized in the Table (opposite).

Progress.-The patient was kept under observation in bed and given a light diet. By September 18 the abdominal symptoms had subsided; there had been no vomiting since admission 5 days earlier, and he was hungry. The body temperature had risen to $102 \cdot 6^{\circ} \mathrm{F}$. and the pulse rate to 116. Severe lightning pains had been occurring in the legs since the previous day. There was no nausea, vomiting, or headache. Re-examination showed that the bladder was distended halfway to the umbilicus. There 
TABLE

EXAMINATIONS OF C.S.F. IN 1961

\begin{tabular}{|c|c|c|c|c|c|c|c|}
\hline Examination & Date & $\begin{array}{c}\text { R.B.C. } \\
\text { (percu. mm.) }\end{array}$ & \multicolumn{3}{|c|}{ W.B.C. (per cu. mm.) } & $\begin{array}{c}\text { Protein } \\
(\mathrm{mg} . ! 100 \mathrm{ml} .)\end{array}$ & \multirow{2}{*}{$\frac{\begin{array}{c}\text { Sugar } \\
(\mathrm{mg} . / 100 \mathrm{ml} .)\end{array}}{\text { Not done }}$} \\
\hline \multirow{5}{*}{$\begin{array}{l}\text { Lumbar } \\
\text { Puncture* }\end{array}$} & Sept. 14 & 59,500 & 20 & $\begin{array}{l}80 \text { per cent. polymorphonuclear leucocytes } \\
20 \text { per cent. lymphocytes }\end{array}$ & . & 80 & \\
\hline & Sept. 19 & - & 2,180 & $\begin{array}{l}\text { Predominantly polymorphonuclear leucocytes } \\
\text { Occasional Gram-positive cocci }\end{array}$ & . & 250 & , , , \\
\hline & Sept. 21 & - & 775 & All polymorphonuclear leucocytes .. & . & 75 & 30 \\
\hline & Sept. 22 & - & 260 & All polymorphonuclear leucocytes .. & . & 100 & 40 \\
\hline & Sept. 24 & 30,000 & 1,200 & Predominantly polymorphonuclear leucocytes & . & 200 & 40 \\
\hline \multirow{4}{*}{$\begin{array}{l}\text { Cisternal } \\
\text { Puncture*† }\end{array}$} & Sept. 25 & 174 & 42 & $\begin{array}{l}90 \text { per cent. polymorphonuclear leucocytes } \\
10 \text { per cent. lymphocytes }\end{array}$ & . & 20 & 90 \\
\hline & Sept. 26 & 142 & 6 & $\begin{array}{l}4 \text { polymorphonuclear leucocytes } \\
2 \text { lymphocytes }\end{array}$ & . & 20 & 80 \\
\hline & Sept. 27 & 31 & 4 & $\begin{array}{l}2 \text { polymorphonuclear leucocytes } \quad \ldots \\
2 \text { lymphocytes }\end{array}$ & . & 30 & 70 \\
\hline & Oct. 2 & 15 & & & & 20 & 60 \\
\hline
\end{tabular}

* All the cultures were sterile.

t Carried out because Charcot's disease of the spine made lumbar puncture difficult and because diarrhoea with faecal incontinence (transient) caused contamination of the lumbar area.

was no neck stiffness, and Kernig's sign was negative. A mid-stream specimen of urine, taken with aseptic precautions, was examined immediately after it had been passed, and a wet film showed many organisms and a few leucocytes; culture gave a profuse growth of enterococci. No other cause for the fever was found.

Treatment.-On the evening of September 18, treatment was started for the urinary infection. He was given $0.5 \mathrm{~g}$. streptomycin by intramuscular injection twice daily, $2 \mathrm{~g}$. sulphadimidine by mouth, followed by $0.5 \mathrm{~g}$. 6-hrly, and potassium citrate mixture, B.P.C., by mouth in sufficient quantity to keep the urine alkaline. He was taught to empty his bladder on waking, after each meal, and last thing at night. Despite the absence of physical signs of meningitis it was decided to re-examine the C.S.F., both because the temperature had risen 2 days after lumbar puncture and because the patient was suffering from tabes, a condition which might conceivably modify the signs and symptoms of meningeal inflammation. Nevertheless, the likely cause of the fever seemed to be the urinary infection. Lumbar puncture on the morning of September 19, 14 hours after treatment with streptomycin and sulphadimidine had been started, showed the C.S.F. to be turbid and yellow. It contained 2,180 W.B.C./cu. mm., predominantly polymorphonuclear leucocytes. The protein content was $250 \mathrm{mg} . / 100 \mathrm{ml}$. Stained films showed occasional Gram-positive cocci. Culture was sterile, which was attributed to the treatment given for urinary infection. The patient still had fever of $101^{\circ} \mathrm{F}$., but was feeling well and was anxious to be allowed up. The lightning pains were less frequent and less severe than on the previous day but were still occurring. Re-examination showed no physical sign of meningitis.

There was a good response to treatment which was with sulphonamides by mouth and streptomycin by intramuscular injection initially, followed by daily intrathecal injections each of $100 \mathrm{mg}$. streptomycin and 20,000 units of penicillin, together with intramuscular injections of $0.75 \mathrm{~g}$. streptomycin twice daily and of 500,000 units penicillin 6-hrly for 7 days. This was followed by intramuscular injections of procaine penicillin 600,000 units daily for a further 13 days because of the possible progression that had occurred in the signs of tabes. At no time was there any headache or physical sign of meningitis. The fever dropped to $99 \cdot 4^{\circ} \mathrm{F}$. after 2 days, and then continued at a low level until the persistent urinary infection had responded to "Furadantin" (100 mg. by mouth 6-hrly for 10 days starting on October 4).

Result--After a period of convalescence, following discharge from hospital, the patient returned to his previous work as a machinist and has since remained well.

\section{Discussion}

Tabes dorsalis may give rise to many diagnostic problems. The "crises" may cause the patient to present with an apparent acute emergency or, conversely, visceral catastrophes may occur without obvious symptoms or physical signs. "Masked" perforation has been reported of peptic ulcers (Hanser, 1919; Carr, 1937; Grimble and Csonka, 1952; Doyle and Campbell, 1953; Lawson, 1961) and of the appendix (Conner, 1910). Painless pneumonia and pleurisy has also been recorded (Sternberg, 1928).

\section{Summary}

A tabetic patient is described, who, in spite of purulent meningitis and fever of over $102^{\circ} \mathrm{F}$., had neither headache nor any physical sign of meningitis, 
We wish to thank Mr B. Fairburn, F.R.C.S., Neurosurgeon to Oldchurch Hospital, and Dr F. M. McGown, Physician to Oldchurch Hospital, for their interest and help.

\section{REFERENCES}

Carr, C. M. (1937). Brit. med. J., 1, 497.

Conner, L. A. (1910). J. Amer. med. Ass., 55, 1427.

Doyle, J. O., and Campbell, D. J. (1953). Brit. J. vener. Dis., 29, 164.

Grimble, A. S., and Csonka, G. W. (1952). Ibid., 28, 61.
Hanser, A. (1919). Dtsch. med. Wschr., 45, 129.

Lawson, J. P. (1961). Postgrad. med. J., 37, 160.

Sternberg, M. (1928). Dtsch. Z. Nervenheilk., 107, 97.

Un tabétique atteint de méningite purulente asymptomatique

\section{RÉSUMÉ}

On décrit un malade atteint de tabes qui, malgré une méningite purulente avec une fièvre de plus de $102^{\circ} \mathrm{F}$. $\left(39^{\circ} \mathrm{C}\right.$.), n'avait ni mal à la tête ni aucune lésion physique. 